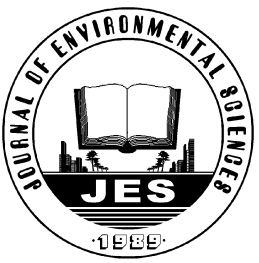

\title{
Health risks associated with heavy metals in the drinking water of Swat, northern Pakistan
}

\author{
Kifayatullah Khan ${ }^{1,2}$, Yonglong Lu ${ }^{2, *}$, Hizbullah Khan ${ }^{1}$, Shahida Zakir ${ }^{1}$, Ihsanullah ${ }^{3}$, Sardar Khan ${ }^{1}$, \\ Akbar Ali Khan ${ }^{1}$, Luo Wei ${ }^{2}$, Tieyu Wang ${ }^{2}$ \\ 1. Department of Environmental Sciences, University of Peshawar, Peshawar 25120, Pakistan. E-mail: mr_khann84@yahoo.com \\ 2. State Key Laboratory of Urban and Regional Ecology, Research Centre for Eco-environmental Sciences, \\ Chinese Academy of Sciences, Beijing 100085, China \\ 3. Nuclear Institute for Food and Agriculture, Tarnab, Peshawar, Pakistan
}

Received 24 December 2012; revised 02 May 2013; accepted 21 May 2013

\begin{abstract}
The concentrations of heavy metals such as $\mathrm{Cd}, \mathrm{Cr}, \mathrm{Cu}, \mathrm{Mn}, \mathrm{Ni}, \mathrm{Pb}$ and $\mathrm{Zn}$ were investigated in drinking water sources (surface and groundwater) collected from Swat valley, Khyber Pakhtunkhwa, Pakistan. The potential health risks of heavy metals to the local population and their possible source apportionment were also studied. Heavy metal concentrations were analysed using atomic absorption spectrometer and compared with permissible limits set by Pakistan Environmental Protection Agency and World Health Organization. The concentrations of $\mathrm{Cd}, \mathrm{Cr}, \mathrm{Ni}$ and $\mathrm{Pb}$ were higher than their respective permissible limits, while $\mathrm{Cu}, \mathrm{Mn}$ and $\mathrm{Zn}$ concentrations were observed within their respective limits. Health risk indicators such as chronic daily intake (CDI) and health risk index (HRI) were calculated for adults and children separately. CDIs and HRIs of heavy metals were found in the order of $\mathrm{Cr}>\mathrm{Mn}>$ $\mathrm{Ni}>\mathrm{Zn}>\mathrm{Cd}>\mathrm{Cu}>\mathrm{Pb}$ and $\mathrm{Cd}>\mathrm{Ni}>\mathrm{Mn}>\mathrm{Cr}>\mathrm{Cu}>\mathrm{Pb}>\mathrm{Zn}$, respectively. HRIs of selected heavy metals in the drinking water were less than 1, indicating no health risk to the local people. Multivariate and univariate statistical analyses showed that geologic and anthropogenic activities were the possible sources of water contamination with heavy metals in the study area.
\end{abstract}

Key words: daily intake; drinking water; health risk; heavy metals; multivariate analysis

DOI: $10.1016 /$ S1001-0742(12)60275-7

\section{Introduction}

Water is considered as a vital substance in the environment (Shah et al., 2012), and its contamination with heavy metals such as cadmium $(\mathrm{Cd})$, chromium $(\mathrm{Cr})$, copper $(\mathrm{Cu})$, manganese $(\mathrm{Mn})$, nickel $(\mathrm{Ni})$, lead $(\mathrm{Pb})$ and zinc $(\mathrm{Zn})$ is a worldwide environmental problem (Muhammad et al., 2011). Generally, heavy metals are released from different natural (i.e., weathering, erosion of bed rocks, ore deposits and volcanic activities) and anthropogenic (i.e., mining, smelting, industrial influx and agricultural activities) sources. They can contaminate the surface (river) and ground (spring, dug well and tube well) water that is used for domestic, agricultural and industrial purposes (Ettler et al., 2012; Krishna et al., 2009; Khan et al., 2008). Surface and ground drinking water contamination is a worldwide health concern, which is becoming increasingly important since 1990s with the unprecedented population growth, urbanization and industrialization (Khan et al.,

\footnotetext{
* Corresponding author. E-mail: yllu@rcees.ac.cn
}

2012; Rapant and Krčmová, 2007).

$\mathrm{pH}$ is one of the most important indicators of water quality and level of pollution in the aquatic ecosystem (Jonnalagadda and Mhere, 2001). Although it has no direct effects on human health, $\mathrm{pH}$ affects some of the water quality parameters such as ionic solubility and pathogens survival, which will impact the human health eventually. In addition, high range $\mathrm{pH}$ confers bitter taste to water (Muhammad et al., 2010; WHO, 2008). Heavy metal enrichment also adversely affects the drinking and irrigation quality of water (Krishna et al., 2009). Ingestion of water containing certain amount of heavy metals may cause health problems in human, including shortness of breath and various types of cancers (Kavcar et al., 2009). Some essential metals like $\mathrm{Cu}, \mathrm{Mn}$ and $\mathrm{Zn}$ are required for normal body growth and function. However, excess amount of these metals could also be harmful. High concentrations of $\mathrm{Cd}, \mathrm{Cr}, \mathrm{Ni}$ and $\mathrm{Pb}$ are considered highly toxic in human and aquatic organisms (Ouyang et al., 2002). Their accumulation in the body can cause serious 
diseases (Khan et al., 2010). The adverse effects of heavy metals include toxic, neurotoxic, carcinogenic, mutagenic and teratogenic effects depending upon the heavy metal species (Sharma et al., 2008; Patra et al., 2010).

In recent years, various epidemiological studies have shown that human exposures to heavy metals are of great concern due to their non-biodegradable nature (Shah et al., 2012). It is recognized that malnourishment and diseases such as abdominal pain, anorexia, cardiovascular diseases, immune dysfunction, hypertension, liver and kidney related disorders, as well as various kinds of cancers could be caused not only by nutrient deficiency, but also by excessive intake of heavy metals in contaminated food and drinking water (Shah et al., 2012; Muhammad et al., 2011; Pekey et al., 2004).

Therefore, it is important to assess the concentrations of heavy metals in drinking water, and their possible sources of contamination. Different multivariate and univariate statistical analyses such as one-way analysis of variance (ANOVA), inter-metals correlation and principal component analysis (PCA) were applied to understand the relationships (Muhammad et al., 2011). These approaches have been previously employed in various studies in other areas of the world to investigate the relationship between contaminated water and human health (Shah et al., 2012; Wen et al., 2011; Avino et al., 2011; Muhammad et al., 2010, 2011; Jang, 2010).

In the area focused in this study, no previous research has been conducted on heavy metal pollution in drinking water. As a result, little information is available on the sources of contamination, and the roles of geological processes (weathering, erosion of mafic and ultramafic rocks) and human activities (mining, agricultural activities, and weak corrosive plumbing systems) (Shah et al., 2010; Kavcar et al., 2009). The present study is designed to investigate the concentrations of heavy metals in drinking water, possible sources of contamination, and their respective potential health risks in Swat Valley, northern Pakistan.

\section{Materials and methods}

\subsection{Study area}

Swat Valley, as shown in Fig. 1, is an administrative district in Khyber Pakhtunkhwa, northern Pakistan. It is situated in the temperate zone of the northern mountain ranges with an altitude ranging from 500 to $6500 \mathrm{~m}$ above the sea level (Qasim et al., 2011). Geographically, the valley stretches from $34^{\circ}$ to $36^{\circ}$ north latitude and from $71^{\circ}$ to $73^{\circ}$ east longitude, with a total area of $5337 \mathrm{~km}^{2}$. It borders Chitral in the north, Gilgit Agency in the northeast, Dir Valley in the west, Buner and Malakand Districts in the south, Shangla and Kohistan Districts in the east, and the Indus River separates it from Hazara in the east. The total population of the region is 1.25 million, with an average density of 248 people per $\mathrm{km}^{2}$ (Qasim et al., 2011). The

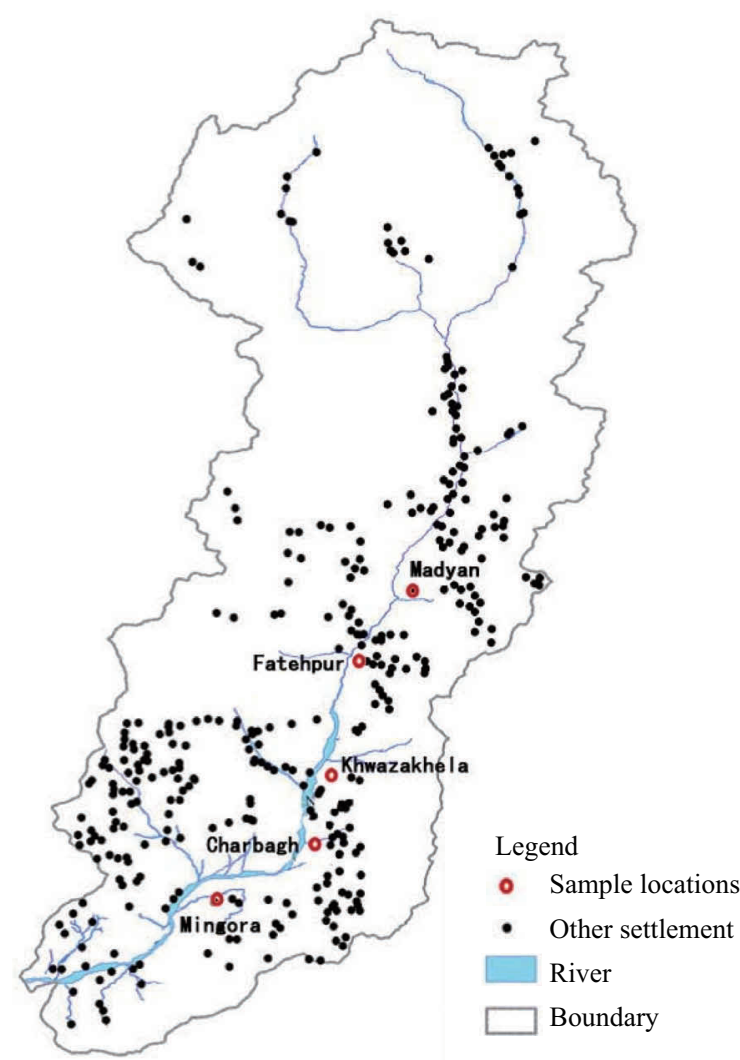

Fig. 1 Location map of the study area showing the sampling sites in Swat valley, northern Pakistan.

Swat River, various springs, tube wells, and dug wells are the water sources for domestic and agricultural purposes. The overall climate of the area can be classified as mediterranean in the northern part and sub-tropical in the southern part. The average temperature fluctuates between $-10^{\circ} \mathrm{C}$ and $25^{\circ} \mathrm{C}$, while the average rainfall varies from 750 to $1350 \mathrm{~mm}$ per year (Shah et al., 2010). The major rainfall normally happens during the monsoon season from June to September. The humidity of the area varies from a minimum of $40 \%$ in April to a maximum of $85 \%$ in July (Nafees et al., 2008). The exposed rocks in the area belong to Indian plate, which is composed of chaotic assemblages of mafic and ultramafic rocks such as serpentinite, green schist, talc-carbonate schist and met basalts (Arif et al., 2011; Shah et al., 2010), along with a discontinuous belt of volcanic, volcano-sedimentary, and sedimentary rocks that have undergone high pressure and low temperature metamorphism.

\subsection{Drinking water sampling}

Surface and groundwater samples were collected from upstream to downstream of Swat River watershed in five locations (Madyan, Fatehpur, Khwazakhela, Charbagh and Mingora) of the study area (Fig. 1). Different sampling procedures were employed for different water sources (Khan et al., 2012). Water of tube well and hand pump was allowed to run for 2 to 5 min before sample collection. In 
the case of stream and river, water samples were collected on the surface. Before water sampling, the gas in the bottles was expelled by filling up. The water was then emptied over the source, and refilled in the same manner. A total of 55 drinking water samples were collected (25 from surface water and 30 from groundwater) from different sampling sites. The $\mathrm{pH}$ was measured on the spot using CONSORT pH meter (Model C931, Turnhout, Belgium). The water samples were collected with clean polyethylene plastic bottles from the selected sampling locations. Before water sampling, the bottles were washed with double deionized water containing $20 \% \mathrm{HNO}_{3}$. Each water sample was filtered and a few drops of $5 \% \mathrm{HNO}_{3}$ were added to prevent further microbial growth. All water samples were placed on ice and transported to the Centralized Resource Laboratory, University of Peshawar, Pakistan, and stored at $4^{\circ} \mathrm{C}$ for further laboratory analysis.

\subsection{Chemical analysis procedures}

Analytical grade chemicals with $99.9 \%$ spectroscopic purity (Merck Darmstadt, Germany) were used for sample preparation and analysis. Double distilled water was used throughout the analysis. Standard solutions of all seven elements were prepared by diluting $1000 \mathrm{mg} / \mathrm{L}$ certified standard solutions (Fluka Kamica, Buchs, Switzerland) of corresponding metal ions. The concentrations of selected heavy metals $(\mathrm{Cd}, \mathrm{Cr}, \mathrm{Cu}, \mathrm{Mn}, \mathrm{Ni}, \mathrm{Pb}$ and $\mathrm{Zn}$ ) in water samples were analysed using graphite furnace atomic absorption spectrometer (GFAAS AAS-700 Perkin Elmer, USA) under standard operating conditions. The integration and delay time of AAS was $5 \mathrm{sec}$. The instrumental detection limits of $\mathrm{Cd}, \mathrm{Cr}, \mathrm{Cu}, \mathrm{Mn}, \mathrm{Ni}, \mathrm{Pb}$ and $\mathrm{Zn}$ were $0.0008,0.0030,0.0015,0.0015,0.0060,0.0150$ and 0.0015 $\mathrm{mg} / \mathrm{L}$, respectively.

\subsection{Approaches for assessing health risks}

\subsubsection{Participatory interviews}

To assess health risks in the study area, participants were randomly selected and interviewed for information about age, body weight, monthly income, smoking habits, occupational exposure, drinking water sources and other health related problems. It was noticed during the meetings and interviews that local people use both surface and groundwater for drinking and other domestic purposes. Therefore, the health risk indicators such as chronic daily intakes (CDIs) and health risk indexes (HRIs) of metals were calculated for both surface and ground drinking water samples.

\subsubsection{Chronic daily intakes of metals}

Heavy metals enter the human body through several pathways including food intake, dermal contact and inhalation. In comparison to oral intake, however, all other pathways are considered negligible (Muhammad et al., 2011). The CDI ( $\mu \mathrm{g} /(\mathrm{kg} \cdot$ day $))$ of heavy metal through water ingestion was calculated by Eq. (1) (Shah et al., 2012; Muhammad et al., 2011).

$\mathrm{CDI}=\frac{C_{\mathrm{m}} \times I_{\mathrm{w}}}{W_{\mathrm{b}}}$

where, $C_{\mathrm{m}}(\mu \mathrm{g} / \mathrm{L})$ means the heavy metal concentration in water, $I_{\mathrm{w}}(\mathrm{L} /$ day $)$ is the average daily intake of water (assumed to be $2 \mathrm{~L} /$ day for adult and $1 \mathrm{~L} /$ day for child) (US EPA, 2011), and $W_{\mathrm{b}}(\mathrm{kg})$ is the average body weights (assumed to be $72 \mathrm{~kg}$ for adult and $32.7 \mathrm{~kg}$ for child), respectively (Muhammad et al., 2011; Khan et al., 2010; Jan et al., 2010).

\subsubsection{Health risk indexes of metals}

To estimate the chronic health risks, HRIs were calculated by Eq. (2) (Shah et al., 2012; Muhammad et al., 2010).

$\mathrm{HRI}=\frac{\mathrm{CDI}}{\mathrm{RfD}}$

where, the oral toxicity reference dose (RfD, $\mu \mathrm{g} /(\mathrm{kg} \cdot$ day $)$ ) values for $\mathrm{Cd}, \mathrm{Cr}, \mathrm{Cu}, \mathrm{Mn}, \mathrm{Ni}, \mathrm{Pb}$ and $\mathrm{Zn}$ are $5.0 \mathrm{E}-$ $01,1.5 \mathrm{E}+03,3.7 \mathrm{E}+01,1.4 \mathrm{E}+02,2.0 \mathrm{E}+01,3.6 \mathrm{E}+01$ and 3.0E +02 , respectively (Shah et al., 2012; Muhammad et al., 2010; US EPA, 2005). The HRI value less than one is considered to be safe for the consumers (Khan et al., 2008).

\subsection{Statistical analysis}

All calculations were conducted using Microsoft Office, version 2010. Multivariate and univariate statistical analyses (e.g., one-way ANOVA, inter-metals correlation and PCA) were carried out using Statistical Package for the Social Sciences, version 17. The location map of the study area was prepared using Arc Geographic Information System.

\section{Results and discussion}

\subsection{Drinking water contamination}

Selected parameters in drinking water samples collected from upstream to downstream of River Swat watershed in the five sampling locations (Madyan, Fatehpur, Khwazakhela, Charbagh and Mingora) are summarized in Table 1. The $\mathrm{pH}$ of the water is considered as one of the most significant water quality parameters in the aquatic system and a high range $\mathrm{pH}$ confers a bitter taste to the drinking water. However, according to the World Health Organization (WHO) (2008), the $\mathrm{pH}$ value in aquatic system has no direct significance in assessing health risks. In this study, the $\mathrm{pH}$ values of surface and ground drinking waters in the five locations were in the decreasing order of Khwazakhela $>$ Madyan $>$ Charbagh $>$ Mingora $>$ 
Fatehpur, and Madyan > Khwazakhela > Charbagh > Mingora $>$ Fatehpur. The lowest $\mathrm{pH}$ value (6.70) was recorded in the surface water of Fatehpur and Mingora, while the highest $\mathrm{pH}$ value (8.60) in the groundwater of Madyan (Table 1). The results indicate that although $\mathrm{pH}$ values of both surface and groundwater samples varied from slightly acidic to slightly alkaline, but they were within the permissible limit as shown in Table 1 and Fig. 2.

Heavy metal concentrations in surface and ground drinking water samples were found in the order of $\mathrm{Cr}>$ $\mathrm{Mn}>\mathrm{Ni}>\mathrm{Zn}>\mathrm{Cd}>\mathrm{Cu}>\mathrm{Pb}$ and $\mathrm{Cr}>\mathrm{Mn}>\mathrm{Ni}>$ $\mathrm{Pb}>\mathrm{Zn}>\mathrm{Cd}>\mathrm{Cu}$, respectively, in the five locations of the study area. The concentrations of $\mathrm{Cd}, \mathrm{Cr}$ and $\mathrm{Ni}$ were higher than their respective permissible limits in all samples, while the $\mathrm{Pb}$ concentration exceeded the permissible limit in $54 \%$ of the water samples. However, $\mathrm{Cu}, \mathrm{Mn}$ and $\mathrm{Zn}$ concentrations in all water samples were found within their respective permissible limits set by Pakistan Environmental Protection Agency (Pak-EPA, 2008) and WHO (2008) (Table 1). The mean Cd concentrations in surface drinking water samples from Madyan, Fatehpur, Khwazakhela, Charbagh and Mingora were $(9.80 \pm 3.27)$, $(11.40 \pm 3.85),(11.80 \pm 2.28),(12.40 \pm 3.85)$ and $(12.60$ $\pm 2.07) \mu \mathrm{g} / \mathrm{L}$, respectively. Its concentrations in ground drinking water samples of these five locations were (11.33 $\pm 3.08),(12.66 \pm 2.58),(13.50 \pm 4.28),(12.00 \pm 1.89)$ and $(13.67 \pm 3.45) \mu \mathrm{g} / \mathrm{L}$, respectively (Table 1). The highest Cd concentration $(17.00 \mu \mathrm{g} / \mathrm{L})$ was recorded in $10.9 \%$ of the collected water samples. This high concentration of $\mathrm{Cd}$ in drinking water could be attributed to the direct contact between water and mafic and ultramafic rocks (Shah et al., 2010), as well as agricultural and industrial contaminations. The mean $\mathrm{Cr}$ concentrations in surface drinking water samples were $(237.00 \pm 23.12),(338.60 \pm$ $77.33),(510.80 \pm 36.69),(549.20 \pm 19.19)$ and $(565.80 \pm$ 25.71) $\mu \mathrm{g} / \mathrm{L}$, and those in ground drinking water samples were $(252.33 \pm 5.65),(395.66 \pm 34.63),(534.50 \pm 8.55)$,
$(569.00 \pm 11.05)$ and $(587.00 \pm 18.08) \mu \mathrm{g} / \mathrm{L}$ in the same five locations, respectively (Table 1). The highest $\mathrm{Cr}$ concentration $(606.00 \mu \mathrm{g} / \mathrm{L})$ was recorded in $3.6 \%$ of the collected water samples. This high $\mathrm{Cr}$ concentration in drinking water samples could be attributed to the presence of mafic and ultramafic rocks in the area, agricultural activities and weak corrosive plumbing systems. Similarly, the highest $\mathrm{Cu}(23 \mu \mathrm{g} / \mathrm{L})$ and $\mathrm{Mn}(157 \mu \mathrm{g} / \mathrm{L})$ concentrations were detected in $1.8 \%$ of the collected water samples. The mean $\mathrm{Ni}$ concentrations in surface drinking water samples were $(48.40 \pm 7.79),(58.60 \pm 6.19),(63.20 \pm$ $4.32),(64.60 \pm 4.16)$ and $(63.20 \pm 3.63) \mu \mathrm{g} / \mathrm{L}$, and those in ground drinking water samples were $(86.83 \pm 4.54)$, $(24.33 \pm 3.20),(83.00 \pm 3.16),(85.00 \pm 6.48)$ and $(47.50$ $\pm 29.59) \mu \mathrm{g} / \mathrm{L}$ in the same five locations, respectively (Table 1). The highest Ni concentration $(94.00 \mu \mathrm{g} / \mathrm{L})$ was detected in $3.6 \%$ of the collected water samples. This high $\mathrm{Ni}$ concentration could be attributed to the erosion of mafic and ultramafic rocks, downstream mining and industrial activities in the area (Arif et al., 2011; Shah et al., 2010; Kavcar et al., 2009). Pb concentrations in all surface drinking water samples were below detection limits (BDL), while its concentrations in ground drinking water samples were $(32.00 \pm 7.09)$, (42.66 \pm 13.92$)$, $(37.67 \pm 13.92),(39.83 \pm 8.38)$ and $(42.17 \pm 24.98)$ $\mu \mathrm{g} / \mathrm{L}$ in the same five locations, respectively (Table 1). The highest $\mathrm{Pb}$ concentration $(75.00 \mu \mathrm{g} / \mathrm{L})$ was detected in $3.6 \%$ of the collected water samples. The elevated $\mathrm{Pb}$ levels in the collected water samples could result from the weathering/leaching of mafic and ultramafic rocks, use of agricultural insecticides and weak corrosive plumbing systems (Shah et al., 2010; Nafees et al., 2009). Zn is an essential trace element found almost in all food and potable water in the form of salts or organic complexes. Its concentrations in surface and ground drinking water samples are shown in Table 1.

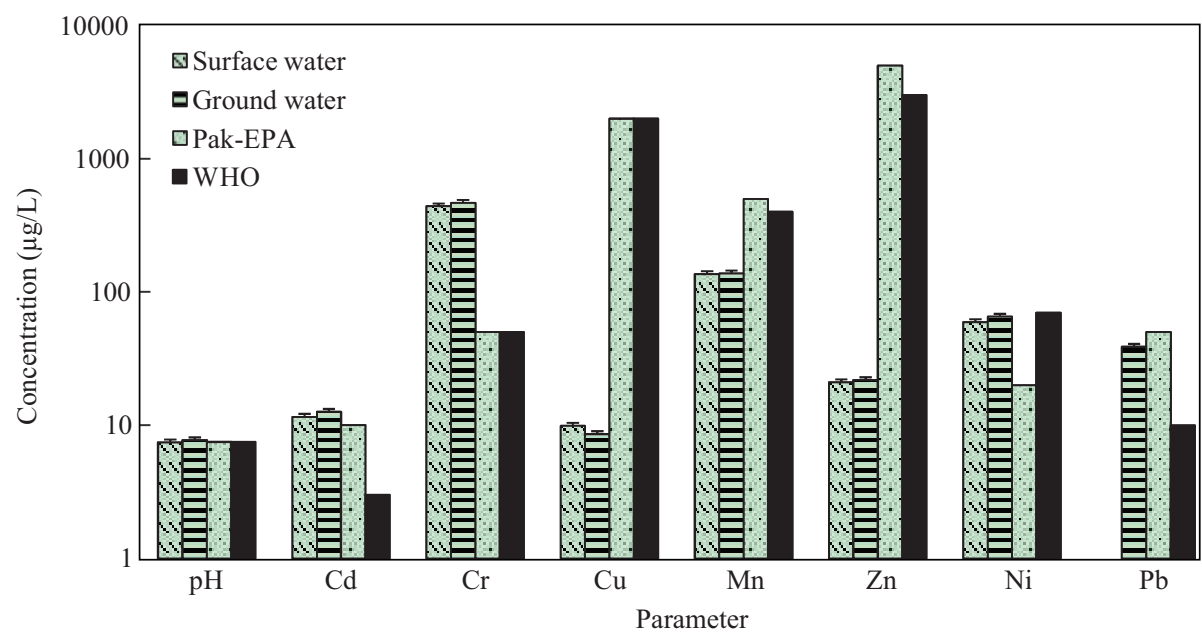

Fig. 2 Comparison of selected parameters in the drinking water along with their permissible limits set by Pak-EPA (2008) and WHO (2008). 
Table $1 \mathrm{pH}$ and concentrations $(\mu \mathrm{g} / \mathrm{L})$ of selected heavy metals in drinking water samples $\left(n^{\mathrm{a}}=55\right)$

\begin{tabular}{|c|c|c|c|c|c|c|c|}
\hline \multirow[t]{2}{*}{ Parameter } & \multirow[t]{2}{*}{ Statistics } & \multicolumn{2}{|c|}{ Madyan } & \multicolumn{2}{|c|}{ Fatehpur } & \multicolumn{2}{|c|}{ Khwazakhela } \\
\hline & & S. water ${ }^{\mathrm{b}} n=5$ & G. water ${ }^{\mathrm{c}} n=6$ & S. water $n=5$ & G. water $n=6$ & S.water $n=5$ & G. water $n=6$ \\
\hline \multirow[t]{3}{*}{$\mathrm{pH}$} & Range & $7.10-7.80$ & $7.30-8.60$ & $6.70-7.90$ & $7.10-7.80$ & $7.20-8.00$ & $7.70-8.10$ \\
\hline & Mean & 7.45 & 7.95 & 7.30 & 7.45 & 7.60 & 7.90 \\
\hline & Stnd. $\mathrm{d}^{\mathrm{f}}$ & \pm 0.49 & \pm 0.92 & \pm 0.85 & \pm 0.49 & \pm 0.57 & \pm 0.28 \\
\hline \multirow[t]{3}{*}{$\mathrm{Cd}$} & Range & $7.00-15.00$ & $8.00-16.00$ & $7.00-16.00$ & $8.00-15.00$ & $9.00-15.00$ & $7.00-17.00$ \\
\hline & Mean & 9.80 & 11.33 & 11.40 & 12.66 & 11.80 & 13.50 \\
\hline & Stnd.d & \pm 3.27 & \pm 3.08 & \pm 3.85 & \pm 2.58 & \pm 2.28 & \pm 4.28 \\
\hline \multirow[t]{3}{*}{$\mathrm{Cr}$} & Range & $215.00-263.00$ & $244.00-258.00$ & $274.00-425.00$ & $361.00-433.00$ & $452.00-552.00$ & $522.00-548.00$ \\
\hline & Mean & 237.00 & 252.33 & 338.60 & 395.66 & 510.80 & 534.50 \\
\hline & Stnd.d & \pm 23.12 & \pm 5.65 & \pm 77.33 & \pm 34.63 & \pm 36.69 & \pm 8.55 \\
\hline \multirow[t]{3}{*}{$\mathrm{Cu}$} & Range & $3.00-8.00$ & $3.00-6.00$ & $4.00-9.00$ & $1.00-6.00$ & $9.00-11.00$ & $4.00-8.00$ \\
\hline & Mean & 5.60 & 4.33 & 5.80 & 03.00 & 10.00 & 6.33 \\
\hline & Stnd.d & \pm 1.95 & \pm 1.21 & \pm 2.17 & \pm 1.89 & \pm 1.00 & \pm 1.37 \\
\hline \multirow[t]{3}{*}{ Mn } & Range & $124.00-137.00$ & $125.00-139.00$ & $128.00-134.00$ & $127.00-141.00$ & $120.00-152.00$ & $128.00-144.00$ \\
\hline & Mean & 131.40 & 131.33 & 130.80 & 131.83 & 135.80 & 135.17 \\
\hline & Stnd.d & \pm 5.03 & \pm 5.39 & \pm 2.39 & \pm 5.23 & \pm 13.74 & \pm 7.05 \\
\hline \multirow[t]{3}{*}{$\mathrm{Ni}$} & Range & $39.00-60.00$ & $81.00-94.00$ & $52.00-68.00$ & $21.00-29.00$ & $58.00-69.00$ & $79.00-87.00$ \\
\hline & Mean & 48.40 & 86.83 & 58.60 & 24.33 & 63.20 & 83.00 \\
\hline & Stnd.d & \pm 7.79 & \pm 4.54 & \pm 6.19 & \pm 3.20 & \pm 4.32 & \pm 3.16 \\
\hline \multirow[t]{3}{*}{$\mathrm{Pb}$} & Range & & $19.00-40.00$ & & $15.00-54.00$ & & $24.00-60.00$ \\
\hline & Mean & $\mathrm{BDL}^{\mathrm{g}}$ & 32.00 & BDL & 42.66 & BDL & 37.67 \\
\hline & Stnd.d & & \pm 7.09 & & \pm 13.92 & & \pm 13.92 \\
\hline \multirow[t]{3}{*}{$\mathrm{Zn}$} & Range & $15.00-26.00$ & $22.00-41.00$ & $17.00-23.00$ & $18.00-27.00$ & $14.00-26.00$ & $17.00-23.00$ \\
\hline & Mean & 22.20 & 27.17 & 20.20 & 20.83 & 20.80 & 19.83 \\
\hline & Stnd.d & \pm 4.27 & \pm 6.97 & \pm 2.59 & \pm 4.07 & \pm 4.82 & \pm 2.71 \\
\hline \multirow[t]{2}{*}{ Parameter } & Statistics & \multicolumn{2}{|c|}{ Charbagh } & \multicolumn{2}{|c|}{ Mingora } & \multicolumn{2}{|c|}{ Permissible limits } \\
\hline & & S. water $n=5$ & G.water $n=6$ & S. water $n=5$ & G. water $n=6$ & Pak-EPA ${ }^{\mathrm{d}}$ & $\mathrm{WHO}^{\mathrm{e}}$ \\
\hline \multirow[t]{3}{*}{$\mathrm{pH}$} & Range & $6.90-7.90$ & $7.60-8.00$ & $6.70-8.10$ & $7.10-7.90$ & $6.50-8.50$ & $6.50-8.50$ \\
\hline & Mean & 7.40 & 7.80 & 7.40 & 7.50 & 7.50 & 7.50 \\
\hline & Stnd.d & \pm 0.71 & \pm 0.28 & \pm 0.99 & \pm 0.57 & \pm 1.41 & \pm 1.41 \\
\hline \multirow[t]{3}{*}{$\mathrm{Cd}$} & Range & $8.00-17.00$ & $9.00-14.00$ & $10.00-15.00$ & $9.00-17.00$ & & \\
\hline & Mean & 12.40 & 12.00 & 12.60 & 13.67 & 10.00 & 03.00 \\
\hline & Stnd.d & \pm 3.85 & \pm 1.89 & \pm 2.07 & \pm 3.45 & & \\
\hline $\mathrm{Cr}$ & Range & $525.00-570.00$ & $557.00-584.00$ & $525.00-595.00$ & $561.00-606.00$ & & \\
\hline & Mean & 549.20 & 569.00 & 565.80 & 587.00 & 50.00 & 50.00 \\
\hline & Stnd.d & \pm 19.19 & \pm 11.05 & \pm 25.71 & \pm 18.08 & & \\
\hline $\mathrm{Cu}$ & Range & $11.00-15.00$ & $7.00-14.00$ & $13.00-16.00$ & $14.00-23.00$ & & \\
\hline & Mean & 13.60 & 10.83 & 14.60 & 18.50 & 2000.00 & 2000.00 \\
\hline & Stnd.d & \pm 1.67 & \pm 2.79 & \pm 1.14 & \pm 3.39 & & \\
\hline $\mathrm{Mn}$ & Range & $134.00-142.00$ & $143.00-146.00$ & $142.00-149.00$ & $144.00-157.00$ & & \\
\hline & Mean & 138.20 & 144.00 & 146.00 & 149.33 & 500.00 & 400.00 \\
\hline & Stnd.d & \pm 3.56 & \pm 1.27 & \pm 2.92 & \pm 4.50 & & \\
\hline $\mathrm{Ni}$ & Range & $58.00-69.00$ & $77.00-93.00$ & $58.00-67.00$ & $23.00-85.00$ & & \\
\hline & Mean & 64.60 & 85.00 & 63.20 & 47.50 & 20.00 & 70.00 \\
\hline & Stnd.d & \pm 4.16 & \pm 6.48 & \pm 3.63 & \pm 29.59 & & \\
\hline $\mathrm{Pb}$ & Range & & $32.00-55.00$ & & $22.00-75.00$ & & \\
\hline & Mean & BDL & 39.83 & BDL & 42.17 & 50.00 & 10.00 \\
\hline & Stnd.d & & \pm 8.38 & & \pm 24.98 & & \\
\hline $\mathrm{Zn}$ & Range & $17.00-25.00$ & $17.00-29.00$ & $17.00-26.00$ & $18.00-29.00$ & & \\
\hline & Mean & 20.20 & 20.17 & 21.80 & 21.16 & 5000.00 & 3000.00 \\
\hline & Stnd.d & \pm 3.56 & \pm 4.45 & \pm 4.09 & \pm 4.99 & & \\
\hline
\end{tabular}

${ }^{\mathrm{a}}$ Number of water samples; ${ }^{\mathrm{b}}$ surface water (river); ${ }^{\mathrm{c}}$ groundwater (spring, dug well and tube well); ${ }^{\mathrm{d}}$ source: Pakistan Environmental Protection Agency (Pak-EPA, 2008); ${ }^{\mathrm{e}}$ source: World Health Organization (WHO, 2008); ${ }^{\mathrm{f}}$ standard deviation; ${ }^{\mathrm{g}}$ below detection limits.

It could be concluded from the results discussed above that in surface water heavy metals such as $\mathrm{Cd}, \mathrm{Cr}, \mathrm{Ni}$ and $\mathrm{Pb}$ showed increasing contamination from upstream to downstream in the region. This tread could be attributed to the presence of mafic and ultramafic rocks, on-going mining and agricultural and industrial contamination in the downstream areas. In the case of groundwater, the heavy metal contaminations varied from upstream to downstream in the five locations. This could be attributed to the geology, corrosion of plumbing systems, and agricultural and industrial activities in the proximity of different groundwater sources. It was also noticed that groundwater contained relatively high concentrations of $\mathrm{Cr}, \mathrm{Cd}, \mathrm{Ni}$ and $\mathrm{Pb}$ as compared to surface water; while the concentrations of $\mathrm{Mn}, \mathrm{Zn}$ and $\mathrm{Cu}$ exhibited little difference between surface and ground drinking water samples (Fig. 2). 


\subsection{Health risk assessments}

\subsubsection{Chronic daily intakes of metals}

The CDI values of selected heavy metals are summarized in Table 2. Based on the drinking water quality in the study area, the CDIs of heavy metals were found in the order of $\mathrm{Cr}>\mathrm{Mn}>\mathrm{Ni}>\mathrm{Zn}>\mathrm{Cd}>\mathrm{Cu}>\mathrm{Pb}$ and $\mathrm{Cr}$ $>\mathrm{Mn}>\mathrm{Ni}>\mathrm{Pb}>\mathrm{Zn}>\mathrm{Cd}>\mathrm{Cu}$ through surface and groundwater consumptions, respectively. Moreover, most of the Cd CDIs exceeded the respective RfD value, while that of $\mathrm{Cr}, \mathrm{Cu}, \mathrm{Mn}, \mathrm{Ni}, \mathrm{Pb}$ and $\mathrm{Zn}$ were within their respective RfD limit set by United States Environmental Protection Agency (US EPA, 2005).

The mean CDIs of $\mathrm{Cd}$ ranged from 0.27 to 0.35 $\mu \mathrm{g} /(\mathrm{kg} \cdot \mathrm{day})$ through surface water consumption, and from 0.32 to $0.38 \mu \mathrm{g} /(\mathrm{kg} \cdot \mathrm{day})$ through groundwater consumption for adults; while they ranged from 0.30 to 0.39 $\mu \mathrm{g} /(\mathrm{kg} \cdot$ day) through surface water consumption, and 0.35 to $0.42 \mu \mathrm{g} /(\mathrm{kg}$.day) through groundwater consumption for children in the selected five locations Madyan, Fatehpur, Khwazakhela, Charbagh and Mingora (Table 2). The lowest Cd CDI $(0.19 \mu \mathrm{g} /(\mathrm{kg} \cdot$ day $)$, for adults) was recorded at Madyan and Fatehpur through surface water consumption, while the highest Cd CDI $(0.52 \mu \mathrm{g} /(\mathrm{kg} \cdot$ day $)$, for children $)$ at Khwazakhela and Mingora through groundwater consumption.
The mean CDIs of $\mathrm{Cr}$ ranged from 6.58 to 15.72 $\mu \mathrm{g} /(\mathrm{kg} \cdot$ day) through surface water consumption, and from 7.01 to $16.31 \mu \mathrm{g} /(\mathrm{kg} \cdot$ day $)$ through groundwater consumption for adults; while they ranged from 7.25 to 17.30 $\mu \mathrm{g} /(\mathrm{kg} \cdot$ day) through surface water consumption, and from 7.72 to $17.95 \mu \mathrm{g} /(\mathrm{kg} \cdot$ day) through groundwater consumption for children in the same five locations. The lowest Cr CDI (5.97 $\mu \mathrm{g} /(\mathrm{kg} \cdot$ day), for adults) was recorded at Madyan through surface water consumption, while the highest Cr CDI (18.53 $\mu \mathrm{g} /(\mathrm{kg} \cdot \mathrm{day})$, for children) at Mingora through groundwater consumption. The highest $\mathrm{Cu}$ $(0.70 \mu \mathrm{g} /(\mathrm{kg} \cdot$ day $))$ and $\mathrm{Mn}(4.65 \mu \mathrm{g} /(\mathrm{kg} \cdot$ day $))$ CDIs were recorded for children at Mingora through groundwater consumption and at Khwazakhela through surface water consumption, respectively. The mean $\mathrm{Ni}$ CDIs ranged from 1.34 to $1.79 \mu \mathrm{g} /(\mathrm{kg} \cdot$ day $)$ through surface water consumption, and from 0.68 to $2.41 \mu \mathrm{g} /(\mathrm{kg} \cdot \mathrm{day})$ through groundwater consumption for adults; while they ranged from 1.48 to $1.98 \mu \mathrm{g} /(\mathrm{kg} \cdot$ day $)$ through surface water consumption, and from 0.74 to $2.66 \mu \mathrm{g} /(\mathrm{kg} \cdot \mathrm{day})$ through groundwater consumption for children in the same five locations (Table 2). The lowest Ni CDI $(0.58 \mu \mathrm{g} /(\mathrm{kg} \cdot$ day $)$, for adults) was recorded at Fatehpur, while the highest $\mathrm{Ni}$ CDI $(2.72 \mu \mathrm{g} /(\mathrm{kg} \cdot$ day $)$, for children $)$ at Charbagh through groundwater consumption. The mean CDIs of $\mathrm{Pb}$ for both adults and children through surface water consumption

Table 2 Chronic daily intakes (CDIs, $\mu \mathrm{g} /(\mathrm{kg} \cdot$ day $)$ ) of heavy metals through drinking water $\left(n^{\mathrm{a}}=55\right)$ consumption

\begin{tabular}{|c|c|c|c|c|c|c|c|c|c|c|c|}
\hline \multirow[t]{2}{*}{ Parameter } & \multirow[t]{2}{*}{ Individuals } & \multicolumn{2}{|c|}{ Madyan } & \multicolumn{2}{|c|}{ Fatehpur } & \multicolumn{2}{|c|}{ Khwazakhela } & \multicolumn{2}{|c|}{ Charbagh } & \multicolumn{2}{|c|}{ Mingora } \\
\hline & & S. water $n=5$ & G. water $n=6$ & S. water $n=5$ & G. water $n=6$ & S. water $n=5$ & G. water $n=6$ & S. water $n=5$ & G. water $n=6$ & S. water $n=5$ & G. water $n=6$ \\
\hline \multirow[t]{2}{*}{$\mathrm{Cd}$} & Adults & $0.27 \pm 0.09$ & $0.32 \pm 0.09$ & $0.32 \pm 0.11$ & $0.35 \pm 0.07$ & $0.33 \pm 0.06$ & $0.38 \pm 0.12$ & $0.34 \pm 0.11$ & $0.33 \pm 0.05$ & $0.35 \pm 0.06$ & $0.38 \pm 0.10$ \\
\hline & Children & $0.30 \pm 0.10$ & $0.35 \pm 0.09$ & $0.35 \pm 0.12$ & $0.39 \pm 0.08$ & $0.36 \pm 0.07$ & $0.41 \pm 0.13$ & $0.38 \pm 0.12$ & $0.37 \pm 0.06$ & $0.39 \pm 0.06$ & $0.42 \pm 0.11$ \\
\hline \multirow[t]{2}{*}{$\mathrm{Cr}$} & Adults & $6.58 \pm 0.64$ & $7.01 \pm 0.16$ & $9.41 \pm 2.15$ & $10.99 \pm 0.96$ & $14.19 \pm 1.02$ & $14.85 \pm 0.24$ & $15.26 \pm 0.53$ & $15.81 \pm 0.31$ & $15.72 \pm 0.71$ & $16.31 \pm 0.50$ \\
\hline & Children & $7.25 \pm 0.71$ & $7.72 \pm 0.17$ & $10.36 \pm 2.36$ & $12.10 \pm 1.06$ & $15.62 \pm 1.12$ & $16.35 \pm 0.26$ & $16.80 \pm 0.59$ & $17.40 \pm 0.34$ & $17.30 \pm 0.79$ & $17.95 \pm 0.55$ \\
\hline \multirow[t]{2}{*}{$\mathrm{Cu}$} & Adults & $0.16 \pm 0.05$ & $0.12 \pm 0.03$ & $0.16 \pm 0.06$ & $0.08 \pm 0.05$ & $0.28 \pm 0.03$ & $0.18 \pm 0.04$ & $0.38 \pm 0.05$ & $0.30 \pm 0.08$ & $0.41 \pm 0.03$ & $0.51 \pm 0.09$ \\
\hline & Children & $0.17 \pm 0.06$ & $0.13 \pm 0.04$ & $0.18 \pm 0.07$ & $0.09 \pm 0.06$ & $0.31 \pm 0.03$ & $0.19 \pm 0.04$ & $0.42 \pm 0.05$ & $0.33 \pm 0.09$ & $0.45 \pm 0.04$ & $0.57 \pm 0.10$ \\
\hline \multirow[t]{2}{*}{$\mathrm{Mn}$} & Adults & $3.65 \pm 0.12$ & $3.65 \pm 0.15$ & $3.63 \pm 0.07$ & $3.66 \pm 0.15$ & $3.77 \pm 0.38$ & $3.76 \pm 0.20$ & $3.84 \pm 0.10$ & $4.00 \pm 0.04$ & $4.06 \pm 0.08$ & $4.15 \pm 0.13$ \\
\hline & Children & $4.02 \pm 0.15$ & $4.02 \pm 0.17$ & $4.00 \pm 0.07$ & $4.03 \pm 0.16$ & $4.15 \pm 0.42$ & $4.13 \pm 0.22$ & $4.23 \pm 0.11$ & $4.40 \pm 0.04$ & $4.47 \pm 0.09$ & $4.57 \pm 0.14$ \\
\hline \multirow[t]{2}{*}{$\mathrm{Ni}$} & Adults & $1.34 \pm 0.22$ & $2.41 \pm 0.13$ & $1.63 \pm 0.17$ & $0.68 \pm 0.09$ & $1.76 \pm 0.12$ & $2.31 \pm 0.09$ & $1.79 \pm 0.12$ & $2.36 \pm 0.18$ & $1.76 \pm 0.10$ & $1.32 \pm 0.82$ \\
\hline & Children & $1.48 \pm 0.24$ & $2.66 \pm 0.14$ & $1.79 \pm 0.19$ & $0.74 \pm 0.10$ & $1.93 \pm 0.13$ & $2.54 \pm 0.10$ & $1.98 \pm 0.13$ & $2.60 \pm 0.20$ & $1.93 \pm 0.11$ & $1.45 \pm 0.90$ \\
\hline \multirow[t]{2}{*}{$\mathrm{Pb}$} & Adults & $\mathrm{NC}^{\mathrm{b}}$ & $0.89 \pm 0.20$ & NC & $1.19 \pm 0.39$ & NC & $1.05 \pm 0.39$ & $\mathrm{NC}$ & $1.11 \pm 0.23$ & $\mathrm{NC}$ & $1.17 \pm 0.69$ \\
\hline & Children & & $0.98 \pm 0.22$ & $\mathrm{NC}$ & $1.31 \pm 0.43$ & $\mathrm{NC}$ & $1.15 \pm 0.43$ & $\mathrm{NC}$ & $1.22 \pm 0.26$ & $\mathrm{NC}$ & $1.29 \pm 0.76$ \\
\hline \multirow[t]{2}{*}{$\mathrm{Zn}$} & Adults & $0.62 \pm 0.12$ & $0.76 \pm 0.19$ & $0.56 \pm 0.07$ & $0.58 \pm 0.11$ & $0.58 \pm 0.13$ & $0.55 \pm 0.08$ & $0.56 \pm 0.10$ & $0.56 \pm 0.12$ & $0.61 \pm 0.11$ & $0.59 \pm 0.14$ \\
\hline & Children & $0.68 \pm 0.13$ & $0.83 \pm 0.21$ & $0.62 \pm 0.08$ & $0.64 \pm 0.13$ & $0.64 \pm 0.15$ & $0.61 \pm 0.08$ & $0.62 \pm 0.11$ & $0.62 \pm 0.14$ & $0.67 \pm 0.13$ & $0.65 \pm 0.15$ \\
\hline
\end{tabular}

a Number of water samples; ${ }^{b}$ not calculated; \pm standard deviation.

Table 3 Health risk indexes (HRIs) of heavy metals through drinking water $\left(n^{\mathrm{a}}=55\right)$ consumption

\begin{tabular}{|c|c|c|c|c|c|c|c|c|c|c|c|}
\hline \multirow[t]{2}{*}{ Parameter } & \multirow[t]{2}{*}{ Individuals } & \multicolumn{2}{|c|}{ Madyan } & \multicolumn{2}{|c|}{ Fatehpur } & \multicolumn{2}{|c|}{ Khwazakhela } & \multicolumn{2}{|c|}{ Charbagh } & \multicolumn{2}{|c|}{ Mingora } \\
\hline & & S. water $n=5$ & G. water $n=6$ & S. water $n=5$ & G. water $n=6$ & S. water $n=5$ & G. water $n=6$ & S. watern $=5$ & G. water $n=6$ & S. water $n=5$ & G. water $n=6$ \\
\hline \multirow[t]{2}{*}{$\mathrm{Cd}$} & Adults & $5.44 \mathrm{E}-01$ & $6.29 \mathrm{E}-01$ & $6.33 \mathrm{E}-01$ & $7.04 \mathrm{E}-01$ & $6.56 \mathrm{E}-01$ & $7.50 \mathrm{E}-01$ & $6.89 \mathrm{E}-01$ & $6.67 \mathrm{E}-01$ & 7.00E-01 & 7.59E-01 \\
\hline & Children & $5.99 \mathrm{E}-01$ & $6.93 \mathrm{E}-01$ & $6.97 \mathrm{E}-01$ & $7.75 \mathrm{E}-01$ & $7.22 \mathrm{E}-01$ & $8.26 \mathrm{E}-01$ & $7.58 \mathrm{E}-01$ & 7.34E-01 & 7.71E-01 & $8.36 \mathrm{E}-01$ \\
\hline \multirow[t]{2}{*}{$\mathrm{Cr}$} & Adults & $4.39 \mathrm{E}-03$ & $4.67 \mathrm{E}-03$ & $6.27 \mathrm{E}-03$ & 7.33E- 03 & $9.46 \mathrm{E}-03$ & $9.90 \mathrm{E}-03$ & $1.02 \mathrm{E}-02$ & $1.05 \mathrm{E}-02$ & $1.05 \mathrm{E}-02$ & $1.09 \mathrm{E}-02$ \\
\hline & Children & $4.80 \mathrm{E}-03$ & $5.10 \mathrm{E}-03$ & $6.90 \mathrm{E}-03$ & $8.10 \mathrm{E}-03$ & $1.04 \mathrm{E}-02$ & $1.09 \mathrm{E}-02$ & $1.12 \mathrm{E}-02$ & $1.16 \mathrm{E}-02$ & $1.15 \mathrm{E}-02$ & $1.20 \mathrm{E}-02$ \\
\hline \multirow[t]{2}{*}{$\mathrm{Cu}$} & Adults & $4.20 \mathrm{E}-03$ & $3.25 \mathrm{E}-03$ & $4.35 \mathrm{E}-03$ & $2.25 \mathrm{E}-03$ & $7.51 \mathrm{E}-03$ & $4.75 \mathrm{E}-03$ & $1.02 \mathrm{E}-02$ & $8.13 \mathrm{E}-03$ & $1.09 \mathrm{E}-02$ & $1.39 \mathrm{E}-02$ \\
\hline & Children & $4.60 \mathrm{E}-03$ & 3.60E-03 & $4.80 \mathrm{E}-03$ & $2.50 \mathrm{E}-03$ & $8.30 \mathrm{E}-03$ & $5.20 \mathrm{E}-03$ & $1.12 \mathrm{E}-02$ & $9.00 \mathrm{E}-03$ & $1.21 \mathrm{E}-02$ & $1.53 \mathrm{E}-02$ \\
\hline \multirow[t]{2}{*}{$\mathrm{Mn}$} & Adults & 2.61E-02 & 2.61E-02 & $2.59 \mathrm{E}-02$ & $2.62 \mathrm{E}-02$ & 2.69E-02 & $2.68 \mathrm{E}-02$ & $2.74 \mathrm{E}-02$ & $2.86 \mathrm{E}-02$ & $2.89 \mathrm{E}-02$ & $2.96 \mathrm{E}-02$ \\
\hline & Children & $2.87 \mathrm{E}-02$ & $2.87 \mathrm{E}-02$ & $2.86 \mathrm{E}-02$ & $2.88 \mathrm{E}-02$ & $2.97 \mathrm{E}-02$ & $2.95 \mathrm{E}-02$ & $3.02 \mathrm{E}-02$ & 3.15E-02 & $3.19 \mathrm{E}-02$ & $3.26 \mathrm{E}-02$ \\
\hline \multirow[t]{2}{*}{$\mathrm{Ni}$} & Adults & $6.72 \mathrm{E}-02$ & $1.21 \mathrm{E}-01$ & $8.14 \mathrm{E}-02$ & 3.38E-02 & 8.78E-02 & $1.15 \mathrm{E}-01$ & $8.97 \mathrm{E}-02$ & $1.18 \mathrm{E}-01$ & $8.78 \mathrm{E}-02$ & $6.59 \mathrm{E}-02$ \\
\hline & Children & $7.40 \mathrm{E}-02$ & $1.33 \mathrm{E}-01$ & $8.96 \mathrm{E}-02$ & $3.72 \mathrm{E}-02$ & $9.66 \mathrm{E}-02$ & $1.27 \mathrm{E}-01$ & $9.88 \mathrm{E}-02$ & $1.30 \mathrm{E}-01$ & $9.66 \mathrm{E}-02$ & 7.26E-02 \\
\hline \multirow[t]{2}{*}{$\mathrm{Pb}$} & Adults & $\mathrm{NC}^{\mathrm{b}}$ & $2.47 \mathrm{E}-02$ & $\mathrm{NC}$ & 3.29E-02 & $\mathrm{NC}$ & $2.91 \mathrm{E}-02$ & $\mathrm{NC}$ & $3.07 \mathrm{E}-02$ & $\mathrm{NC}$ & 3.25E-02 \\
\hline & Children & & $2.72 \mathrm{E}-02$ & & 3.62E-02 & & $3.20 \mathrm{E}-02$ & & 3.38E-02 & & $3.58 \mathrm{E}-02$ \\
\hline \multirow[t]{2}{*}{$\mathrm{Zn}$} & Adults & $2.06 \mathrm{E}-03$ & $2.52 \mathrm{E}-03$ & $1.87 \mathrm{E}-03$ & $1.93 \mathrm{E}-03$ & $1.93 \mathrm{E}-03$ & $1.84 \mathrm{E}-03$ & $1.87 \mathrm{E}-03$ & $1.87 \mathrm{E}-03$ & $2.20 \mathrm{E}-03$ & $1.96 \mathrm{E}-03$ \\
\hline & Children & $2.30 \mathrm{E}-03$ & $2.80 \mathrm{E}-03$ & $2.10 \mathrm{E}-03$ & $2.10 \mathrm{E}-03$ & $2.10 \mathrm{E}-03$ & $2.00 \mathrm{E}-03$ & $2.10 \mathrm{E}-03$ & $2.10 \mathrm{E}-03$ & $2.20 \mathrm{E}-03$ & $2.20 \mathrm{E}-03$ \\
\hline
\end{tabular}


were not calculated because the concentrations of $\mathrm{Pb}$ in surface water samples were recorded BDL. However, through groundwater consumption the mean CDIs of $\mathrm{Pb}$ ranged from 0.89 to $1.19 \mu \mathrm{g} /(\mathrm{kg} \cdot$ day) for adults; while they ranged from 0.98 to $1.31 \mu \mathrm{g} /(\mathrm{kg} \cdot$ day) for children. The highest $\mathrm{Pb}$ CDI $(2.29 \mu \mathrm{g} /(\mathrm{kg} \cdot$ day $))$ was recorded for children at Mingora through groundwater consumption. For $\mathrm{Zn}$ CDIs the lowest value $(0.38 \mu \mathrm{g} /(\mathrm{kg} \cdot$ day $)$, for adults) was recorded at Khwazakhela through surface water consumption, while the highest value $(0.89 \mu \mathrm{g} /(\mathrm{kg} \cdot$ day $)$, for children) at Charbagh and Mingora through groundwater consumption.

\subsubsection{Health risk indexes of metals}

The HRI values of selected heavy metals are summarized in Table 3. Based on the drinking water quality, the HRIs of selected heavy metals were found in the order of $\mathrm{Cd}$ $>\mathrm{Ni}>\mathrm{Mn}>\mathrm{Cr}>\mathrm{Cu}>\mathrm{Zn}>\mathrm{Pb}$ and $\mathrm{Cd}>\mathrm{Ni}>\mathrm{Pb}$ $>\mathrm{Mn}>\mathrm{Cr}>\mathrm{Cu}>\mathrm{Zn}$ through surface and groundwater consumptions, respectively.

In the five locations, the HRIs of $\mathrm{Cd}$ for adults were 5.44E-01, 6.33E-01, 6.56E-01, 6.89E-01 and 7.00E01 respectively through surface water consumption, and 6.29E-01, 7.04 E-01, 7.50E-01, 6.67E-01 and 7.59E01 respectively through groundwater consumption. For children the HRIs of Cd were 5.99E-01, 6.97E-01, 7.22E01, 7.58E-01 and 7.71E-01 respectively through surface water consumption, and 6.93E-01, 7.75E-01, 8.26E-01, 7.34E-01 and 8.36E-01 respectively through groundwater consumption. The HRIs of $\mathrm{Cr}$ for adults were 4.39E-03, 6.27E-03, 9.46E-03, 1.02E-02 and 1.05E-02 respectively through surface water consumption, and 4.67E-03, 7.33E-03, 9.90E-03, 1.05E-02 and 1.09E-02 respectively through groundwater consumption. For children the HRIs of $\mathrm{Cr}$ were $4.80 \mathrm{E}-03,6.90 \mathrm{E}-03,1.04 \mathrm{E}-02,1.12 \mathrm{E}-02$ and $1.15 \mathrm{E}-02$ respectively through surface water consumption, and $5.10 \mathrm{E}-03,8.10 \mathrm{E}-03,1.09 \mathrm{E}-02,1.16 \mathrm{E}-02$ and $1.20 \mathrm{E}-$ 02 respectively through groundwater consumption. The HRIs of $\mathrm{Ni}$ for adults were 6.72E-02, 8.14E-02, 8.78E$02,8.97 \mathrm{E}-02$ and $8.78 \mathrm{E}-02$ respectively through surface water consumption, and $1.21 \mathrm{E}-01,3.38 \mathrm{E}-02,1.15 \mathrm{E}-01$, $1.18 \mathrm{E}-01$ and $6.59 \mathrm{E}-02$ respectively through groundwater consumption. For children the HRIs of Ni were 7.40E-02, 8.96E-02, 9.66E-02, 9.88E-02 and 9.66E-02 respectively through surface water consumption, and 1.33E-01, 3.72E$02,1.27 \mathrm{E}-01,1.30 \mathrm{E}-01$ and $7.26 \mathrm{E}-02$ respectively, through groundwater consumption in the five locations. For both adults and children the HRIs of $\mathrm{Pb}$ through surface water consumption were not calculated, because the concentrations of $\mathrm{Pb}$ in surface water samples were BDL. For groundwater consumption the HRIs of $\mathrm{Pb}$ were $2.47 \mathrm{E}-02$, 3.29E-02, 2.91E-02, 3.07E-02 and 3.25E-02 respectively for adults, and 2.72E-02, 3.62E-02, 3.20E-02, 3.38E-02 and 3.58E-02 respectively for children. The HRIs of $\mathrm{Zn}$, $\mathrm{Cu}$, and $\mathrm{Mn}$ for both adults and children are shown in Table 3.
The data in Table 3 demonstrated that the HRI values in this study were within safe limits $($ HRI $<1)$, suggesting no health risk in this region (Muhammad et al., 2011). However, the HRIs of $\mathrm{Cd}, \mathrm{Cr}, \mathrm{Mn}$ and $\mathrm{Ni}$ were higher (Fig. 3) in this study compared to studies conducted by Muhammad et al. (2011) and Shah et al. (2012) in this country.

\subsection{Statistical analysis}

\subsubsection{One-way ANOVA comparison}

One-way ANOVA was used for the statistical comparison of selected heavy metal pollutions in different sampling locations. Results showed significant variation $(P<0.05)$ between these locations, suggesting that different locations contribute differently to the mean metal concentrations in the drinking water. However, each heavy metal had a different variation value for an individual location in the study area (Fig. 4).

Post hoc (Tukey test) demonstrated that Cr concentrations were significantly higher $(P<0.05)$ in ground water samples collected from Mingora area as compared to the surface water from Madyan, Fatehpur and Khwazakhela areas, and groundwater from Madyan and Fatehpur areas (Fig. 4b). $\mathrm{Cu}$ concentrations were found significantly higher $(P<0.05)$ in groundwater samples collected from Mingora as compared to surface and groundwater samples collected from the other four locations (Fig. 4c). Mn concentrations were also significantly higher $(P<0.05)$ in groundwater samples collected from Mingora area as compared to surface and groundwater samples collected from Madyan, Fatehpur, and Khwazakhela areas (Fig. 4d). $\mathrm{Ni}$ concentrations were higher $(P<0.05)$ in groundwater samples collected from Madyan area as compared to surface water samples from Madyan, Fatehpur, Khwazakhela, Charbagh and Mingora areas, and groundwater samples from Fatehpur and Mingora areas (Fig. 4e). However, Post hoc (Tukey test) showed no significant differences $(P>0.05)$ between the concentrations of $\mathrm{Cd}, \mathrm{Pb}$ and $\mathrm{Zn}$ in drinking water samples collected from the same five

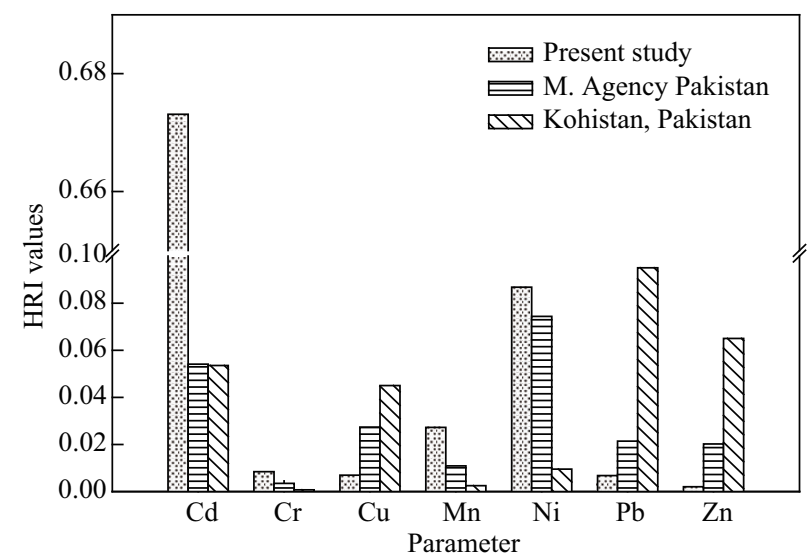

Fig. 3 Comparison of the present work with previous studies carried out in different parts of Pakistan. 

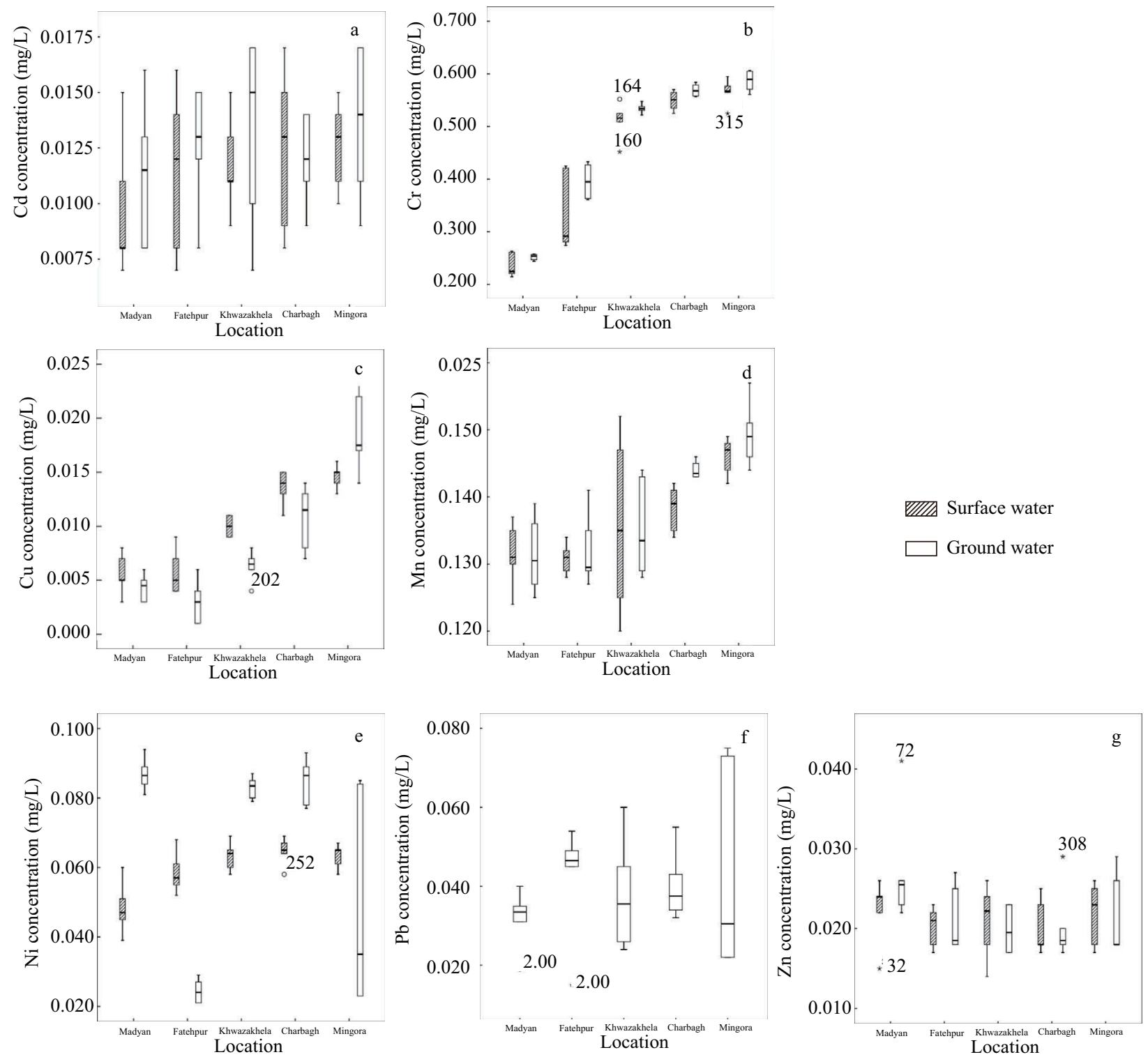

Fig. 4 One-way ANOVA boxplots comparison for $\mathrm{Cd}(\mathrm{a}), \mathrm{Cr}(\mathrm{b}), \mathrm{Cu}(\mathrm{c}), \mathrm{Mn}(\mathrm{d}), \mathrm{Ni}(\mathrm{e}), \mathrm{Pb}(\mathrm{f})$ and $\mathrm{Zn}(\mathrm{g})$.

locations (Madyan, Fatehpur, Khwazakhela, Charbagh and Mingora) (Fig. 4a, $\mathbf{f}$ and $\mathbf{g}$ ).

\subsubsection{Inter-metal correlation}

The inter-metal correlation analysis provides valuable information about the heavy metal concentrations and their respective pathways (Muhammad et al., 2011). The Intermetal correlation of selected heavy metals in surface and ground drinking water samples are summarized in Table 4.

In surface water samples, the correlation analysis showed positive correlations in some heavy metal pairs such as Cr-Cu ( $r=0.818), \mathrm{Cr}-\mathrm{Mn}(r=0.548), \mathrm{Cr}-\mathrm{Ni}(r=$ $0.763), \mathrm{Cu}-\mathrm{Mn}(r=0.557)$ and $\mathrm{Cu}-\mathrm{Ni}(r=0.459)$. However, no correlation existed for $\mathrm{Pb}$ because the concentrations of $\mathrm{Pb}$ in surface water samples were BDL. In the case of groundwater samples, the correlation analysis revealed positive correlations in several metal pairs such as $\mathrm{Cr}-\mathrm{Cu}$ $(r=0.669), \mathrm{Cr}-\mathrm{Mn}(r=0.666)$ and $\mathrm{Cu}-\mathrm{Mn}(r=0.792)$. Interestingly, a negative correlation $(r=-0.462)$ was noted for $\mathrm{Cr}-\mathrm{Zn}$ pair.

\subsubsection{Principle component analysis}

To assess the qualitative behaviour of clustering, PCA (Varimax Kaiser Normalization) with three factors was applied for both surface and ground drinking water samples. Table 5 summarizes the components and rotational component matrixes for both surface and ground drinking water samples.

PCA revealed that the total cumulative variance for three factors in surface water samples was $82.126 \%$, in which Factor- 1 contributed $42.439 \%$ to the total variance with a high loading on $\mathrm{Cr}(r=0.943), \mathrm{Cu}(r=0.846)$ and $\mathrm{Ni}(r=0.823)$ (Table 5). $\mathrm{Cr}$ and $\mathrm{Ni}$ contaminations could result from the erosion of mafic and ultramafic 
rocks, and mining and industrial activities in the area. On the other hand $\mathrm{Cu}$ level could be influenced more by agricultural activities. The results suggest that Factor-1 may have both geologic and anthropogenic contributions. Factor- 2 contributed $20.017 \%$ to the total variance with a high loading on $\mathrm{Zn}(r=0.763)$, Mn $(r=0.691)$ and $\mathrm{Cu}$ $(r=0.280)$. Mn and $\mathrm{Zn}$ levels could be affected by the erosion of mafic and ultramafic rocks, while $\mathrm{Cu}$ level could be influenced by local agricultural activities. The results suggest that Factor-2 may also represent both geologic and anthropogenic sources. Factor-3 contributed $19.669 \%$ to the total variance with a high loading on $\mathrm{Cd}(r=0.942)$, Mn $(r=0.298)$ and $\mathrm{Cr}(r=0.216)$. Cd level elevation could be caused by the erosion of schistose rocks, while $\mathrm{Mn}$ and $\mathrm{Cr}$ could be the result of the weathering of mafic and ultramafic rocks. These results suggest that Factor-3 may have only geologic contributions.

In the case of groundwater, the total cumulative variance for three factors was $75.900 \%$, in which Factor-1 contributed $35.074 \%$ to the total variance with a high loading on $\mathrm{Cu}(r=0.929), \mathrm{Mn}(r=0.905)$ and $\mathrm{Cr}(r=0.810) . \mathrm{Cr}$ and $\mathrm{Mn}$ contaminations could result from the erosion of mafic and ultramafic rocks and the corrosion of plumbing systems, while $\mathrm{Cu}$ level could be influenced by local agricultural activities. The results indicate that Factor-1 may have both geologic and anthropogenic contributions. Factor- 2 contributed $21.639 \%$ to the total variance with a high loading on $\mathrm{Cd}(r=0.761)$ and $\mathrm{Pb}(r=0.587)$. Cd level could be affected by the weathering of mafic and ultramafic rocks, while $\mathrm{Pb}$ level could be influenced by plumbing systems in Fatehpur and Charbagh areas. The results indicate that Factor-2 may also represent both geologic and anthropogenic sources. Factor- 3 contributed

Table 4 Correlation matrixes of selected heavy metals in the drinking water $\left(n^{\mathrm{a}}=55\right)$

\begin{tabular}{llllllll}
\hline $\begin{array}{l}\text { Surface water } \\
(n=25)\end{array}$ & $\mathrm{Cd}$ & $\mathrm{Cr}$ & $\mathrm{Cu}$ & $\mathrm{Mn}$ & $\mathrm{Ni}$ & $\mathrm{Pb}$ & $\mathrm{Zn}$ \\
\hline $\mathrm{Cd}$ & 1.000 & & & & & & \\
$\mathrm{Cr}$ & 0.350 & 1.000 & & & & & \\
$\mathrm{Cu}$ & 0.129 & $0.818^{* *}$ & 1.000 & & & & \\
$\mathrm{Mn}$ & 0.157 & $0.548^{* *}$ & $0.557^{* *}$ & 1.000 & & & \\
$\mathrm{Ni}$ & 0.340 & $0.763^{* *}$ & $0.459^{*}$ & 0.258 & 1.000 & & \\
$\mathrm{~Pb}$ & $\mathrm{NC}$ & $\mathrm{NC}$ & $\mathrm{NC}$ & $\mathrm{NC}$ & $\mathrm{NC}$ & $\mathrm{NC}$ & \\
$\mathrm{Zn}$ & 0.123 & -0.680 & 0.022 & 0.165 & -0.132 & $\mathrm{NC}$ & 1.000 \\
\hline
\end{tabular}

\section{Groundwater}

$(n=30)$

\begin{tabular}{llllllll}
\hline $\mathrm{Cd}$ & 1.000 & & & & & & \\
$\mathrm{Cr}$ & 0.239 & 1.000 & & & & & \\
$\mathrm{Cu}$ & 0.176 & $0.669^{* *}$ & 1.000 & & & & \\
$\mathrm{Mn}$ & 0.321 & $0.666^{* *}$ & $0.792^{* *}$ & 1.000 & & & \\
$\mathrm{Ni}$ & -0.300 & -0.042 & -0.032 & -0.082 & 1.000 & & \\
$\mathrm{~Pb}$ & 0.261 & 0.182 & -0.042 & 0.103 & -0.287 & 1.000 & \\
$\mathrm{Zn}$ & -0.010 & $-0.462^{*}$ & -0.013 & -0.216 & 0.167 & -0.281 & 1.000 \\
\hline
\end{tabular}

${ }^{\mathrm{a}}$ Number of water samples; ${ }^{\mathrm{b}}$ not calculated.

** Correlation is significant at the 0.01 level (2-tailed); ${ }^{*}$ correlation is significant at the 0.05 level (2-tailed).
Table 5 Factor loading for selected heavy metals in the drinking water $\left(n^{\mathrm{a}}=55\right)$

\begin{tabular}{|c|c|c|c|c|c|c|}
\hline & \multicolumn{3}{|c|}{ Component matrix } & \multicolumn{3}{|c|}{ Rotated component matrix } \\
\hline & Factor 1 & Factor 2 & Factor 3 & Factor 1 & Factor 2 & Factor 3 \\
\hline \multicolumn{7}{|c|}{ Surface water $(n=25)$} \\
\hline $\mathrm{Cd}$ & 0.450 & -0.616 & 0.581 & 0.153 & -0.101 & $0.942^{b}$ \\
\hline $\mathrm{Cr}$ & 0.962 & 0.020 & -0.145 & 0.943 & 0.107 & 0.216 \\
\hline $\mathrm{Cu}$ & 0.835 & 0.269 & -0.159 & 0.846 & 0.280 & 0.018 \\
\hline $\mathrm{Mn}$ & 0.663 & 0.419 & 0.418 & 0.474 & 0.691 & 0.298 \\
\hline $\mathrm{Ni}$ & 0.775 & -0.204 & -0.317 & 0.823 & -0.203 & 0.153 \\
\hline $\mathrm{Pb}$ & $\mathrm{NC}^{\mathrm{c}}$ & $\mathrm{NC}$ & $\mathrm{NC}$ & $\mathrm{NC}$ & $\mathrm{NC}$ & $\mathrm{NC}$ \\
\hline $\mathrm{Zn}$ & -0.105 & 0.826 & 0.199 & -0.123 & 0.763 & -0.366 \\
\hline Total & 2.877 & 1.352 & 0.699 & 2.546 & 1.201 & 1.180 \\
\hline Variance (\%) & 47.953 & 22.531 & 11.642 & 42.439 & 20.017 & 19.669 \\
\hline Cumulative (\%) & 47.953 & 70.484 & 82.126 & 42.439 & 62.456 & 82.126 \\
\hline \multicolumn{7}{|c|}{ Groundwater $(n=30)$} \\
\hline $\mathrm{Cd}$ & 0.462 & -0.371 & 0.591 & 0.299 & 0.761 & 0.176 \\
\hline $\mathrm{Cr}$ & 0.871 & 0.135 & -0.256 & 0.810 & 0.044 & -0.429 \\
\hline $\mathrm{Cu}$ & 0.793 & 0.464 & 0.171 & 0.929 & -0.001 & 0.101 \\
\hline $\mathrm{Mn}$ & 0.877 & 0.261 & 0.099 & 0.905 & 0.144 & -0.078 \\
\hline $\mathrm{Ni}$ & -0.253 & 0.658 & -0.298 & 0.043 & -0.753 & 0.132 \\
\hline $\mathrm{Pb}$ & 0.309 & -0.706 & -0.105 & -0.052 & 0.587 & -0.507 \\
\hline $\mathrm{Zn}$ & -0.43 & 0.369 & 0.734 & -0.147 & -0.024 & 0.915 \\
\hline Total & 2.713 & 1.507 & 1.093 & 2.455 & 1.515 & 1.343 \\
\hline Variance (\%) & 38.757 & 21.525 & 15.619 & 35.074 & 21.639 & 19.187 \\
\hline Cumulative (\%) & 38.757 & 60.282 & 75.900 & 35.074 & 56.713 & 75.900 \\
\hline
\end{tabular}

$19.187 \%$ to the total variance with a high loading on $\mathrm{Zn}(r=0.915), \mathrm{Cd}(r=0.176)$ and $\mathrm{Ni}(r=0.132)$. Ni level could be influenced by the weathering of mafic and ultramafic rocks, while $\mathrm{Zn}$ and $\mathrm{Cd}$ could come from the schistose rocks with sulfide seams. These results indicate that Factor-3 may have only geologic contributions.

\section{Conclusions}

Heavy metal concentrations were the highest for $\mathrm{Cr}$ followed by $\mathrm{Mn}>\mathrm{Ni}>\mathrm{Zn}>\mathrm{Cd}>\mathrm{Cu}>\mathrm{Pb}$ in the drinking water collected from both surface and groundwater sources. $\mathrm{Cd}, \mathrm{Cr}, \mathrm{Ni}$ and $\mathrm{Pb}$ concentrations were higher than their respective permissible limits set by Pak-EPA and WHO, while $\mathrm{Cu}, \mathrm{Mn}$ and $\mathrm{Zn}$ concentrations were within their limits. The ANOVA analysis showed that heavy metal contaminations at different locations varied significantly $(P<0.05)$. Inter-metal correlation of metals in both surface and groundwater showed a strong correlation between metal pairs. Moreover, the PCA results revealed that both geologic and anthropogenic sources were responsible for the heavy metals contamination of the drinking water in Madyan, Fatehpur, Khwazakhela, Charbagh and Mingora areas. According to health risk assessment, no health risk was observed in the area (HRI $<1$ ) based on US EPA standards, while multi-fold higher concentrations of $\mathrm{Cd}$, $\mathrm{Cr}, \mathrm{Ni}$, and $\mathrm{Pb}$ may pose potential health risks to the local inhabitants. Therefore, it is strongly recommended that water from contaminated locations should not be used for drinking purposes without proper treatment. The Government of Pakistan should provide drinking water alternatives to these areas in recognition of the potential 
health risks associated with heavy metals.

\section{Acknowledgments}

The financial assistance for this research was provided by the Chinese Academy of Sciences and the World Academy of Sciences under FR Number: 3240255020, in the form of one year Postgraduate Fellowship to the first author. The authors are thankful to Dr. Chengfang Pang, Research Centre for Eco-environmental Sciences, Chinese Academy of Sciences, Beijing, China, for assistance with statistical analysis and Dr. Ahmed Khan, Institute of Geographic Sciences and National Resources, Chinese Academy of Sciences, Beijing, China, for helpful comments on clarity and style.

\section{References}

Arif M, Henry D J, Moon C J, 2011. Host rock characteristics and source of chromium and beryllium for emerald mineralization in the ophiolitic rocks of the Indus Suture Zone in Swat, NW Pakistan. Ore Geology Reviews, 39(1-2): 1-20.

Avino P, Capannesi G, Rosada A, 2011. Ultra-trace nutritional and toxicological elements in Rome and Florence drinking waters determined by Instrumental Neutron Activation Analysis. Microchemical Journal, 97(2): 144-153.

Ettler V, Kř’ıbek B, Majer V, Knésl I, Mihaljevič M, 2012. Differences in the bioaccessibility of metals/metalloids in soils from mining and smelting areas (Copperbelt, Zambia). Journal of Geochemical Exploration, 113: 68-75.

Jan F A, Ishaq M, Khan S, Ihsanullah I, Ahmad I, Shakirullah M, 2010. A comparative study of human health risks via consumption of food crops grown on wastewater irrigated soil (Peshawar) and relatively clean water irrigated soil (lower Dir). Journal of Hazardous Materials, 179(1-3): 612-621.

Jang C S, 2010. Applying scores of multivariate statistical analyses to characterize relationships between hydrochemical properties and geological origins of springs in Taiwan. Journal of Geochemical Exploration, 105(1-2): 11-18.

Jonnalagadda S B, Mhere G, 2001. Water quality of the Odzi River in the eastern highlands of Zimbabwe. Water Research, 35(10): 2371-2376.

Kavcar P, Sofuoglu A, Sofuoglu S C, 2009. A health risk assessment for exposure to trace metals via drinking water ingestion pathway. International Journal of Hygiene and Environmental Health, 212(2): 216-227.

Khan S, Cao Q, Zheng Y M, Huang Y Z, Zhu Y G, 2008. Health risks of heavy metals in contaminated soils and food crops irrigated with wastewater in Beijing, China. Environmental Pollution, 152(3): 686-692.

Khan S, Rehman S, Khan A Z, Khan M A, Shah M T, 2010. Soil and vegetables enrichment with heavy metals from geological sources in Gilgit, northern Pakistan. Ecotoxicology and Environmental Safety, 73(7): 1820-1827.

Khan S, Shahnaz M, Jehan N, Rehman S, Shah M T, Din I, 2012. Drinking water quality and human health risk in Charsadda district, Pakistan. Journal of Cleaner Production. DOI: 10.1016/j.jclepro.2012.02.016.
Krishna A K, Satyanarayanan M, Govil P K, 2009. Assessment of heavy metal pollution in water using multivariate statistical techniques in an industrial area: a case study from Patancheru, Medak District, Andhra Pradesh, India. Journal of Hazardous Materials, 167(1-3): 366-373.

Muhammad S, Shah M T, Khan S, 2010. Arsenic health risk assessment in drinking water and source apportionment using multivariate statistical techniques in Kohistan region, northern Pakistan. Food and Chemical Toxicology, 48(10): 2855-2864.

Muhammad S, Shah M T, Khan S, 2011. Health risk assessment of heavy metals and their source apportionment in drinking water of Kohistan region, northern Pakistan. Microchemical Journal, 98(2): 334-343.

Nafees M, Jan M R, Khan H, Ali A, 2008. Status of soil texture and required associated soil conservation measure of river Swat catchment area, NWFP, Pakistan. Sarhad Journal of Agriculture, 24(2): 251-259.

Nafees M, Jan M R, Khan H, Rashid N, Khan F, 2009. Soil contamination in Swat valley caused by cadmium and copper. Sarhad Journal of Agriculture, 25(1): 37-43.

Ouyang Y, Higman J, Thompson J, OToole O T, Campbell D, 2002. Characterization and spatial distribution of heavy metals in sediment from Cedar and Ortega Rivers subbasin. Journal of Contaminant Hydrology, 54(1-2): 19-35.

Pak-EPA, 2008. National Standards for Drinking Water Quality. Pakistan Environmental Protection Agency, Ministry of Environment Pakistan.

Patra A K, Wagh S S, Jain A K, Hegde A G, 2010. Assessment of daily intake of trace elements by Kakrapar adult population through ingestion pathway. Environmental Monitoring and Assessment, 169(1-4): 267-272.

Pekey H, Karakaş D, Bakoğlu M, 2004. Source apportionment of trace metals in surface waters of a polluted stream using multivariate statistical analysis. Marine Pollution Bulletin, 49(9-10): 809-818.

Qasim M, Hubacek K, Termansen M, Khan A, 2011. Spatial and temporal dynamics of land use pattern in District Swat, Hindu Kush Himalayan region of Pakistan. Applied Geography, 31(2): 820-828.

Rapant S, Krčová K, 2007. Health risk assessment maps for arsenic groundwater content, application of national geochemical databases. Environmental Geochemistry and Health, 29(2): 131-141.

Shah H U, Simpson T J, Alam S, Khattak K F, Perveen S, 2010a. Mould incidence and mycotoxin contamination in maize kernels from Swat Valley, North West Frontier Province of Pakistan. Food and Chemical Toxicology, 48(4): 11111116.

Shah M T, Ara J, Muhammad S, Khan S, Tariq S, 2012. Health risk assessment via surface water and sub-surface water consumption in the mafic and ultramafic terrain, Mohmand agency, northern Pakistan. Journal of Geochemical Exploration, 118: 60-67.

Shah M T, Begum S, Khan S, 2010b. Pedo and biogeochemical studies of mafic and ultramfic rocks in the Mingora and Kabal areas, Swat, Pakistan. Environmental Earth Sciences, 60(5): 1091-1102.

Sharma R K, Agrawal M, Marshall F M, 2008. Heavy metal (Cu, $\mathrm{Zn}, \mathrm{Cd}$ and $\mathrm{Pb}$ ) contamination of vegetables in urban India: 
A case study in Varanasi. Environmental Pollution, 154(2): 254-263.

US EPA, 2005. Guidelines for carcinogen risk assessment. Risk Assessment Forum, United States Environmental Protection Agency, Washington, DC. EPA/630/P-03/001F.

US EPA, 2011. Exposure Factors Handbook. United States Environmental Protection Agency, Washington, DC. EPA/600/R-09/052F.
Wen X D, Yang Q L, Yan Z D, Deng Q W, 2011. Determination of cadmium and copper in water and food samples by dispersive liquid-liquid microextraction combined with UV-vis spectrophotometry. Microchemical Journal, 97(2): 249-254.

WHO, 2008. Guidelines for Drinking-Water Quality 3rd edition, Vol.1, Recommendations. World Health Organisation, Geneva. 